\title{
Harmonization of Environmental Laws Based On Democracy Justice Principle and Sustainability
}

\author{
Said Sampara ${ }^{1}$, Abdul Agis ${ }^{1}$, Hamza Baharuddin ${ }^{1}$, Rahmat $^{1,2}$ \\ ${ }^{I}$ Faculty of Law Universitas Muslim Indonesia, Indonesia \\ ${ }^{2}$ Faculty of Law, Unversitas Tomakaka, Indonesia
}

\begin{abstract}
Implementation of national development that utilizes natural resources, environmental legislation becomes an important aspect as the legal basis. This research uses normative juridical approach, through the approach of legislation approach, conceptual approach and anlytis approach. Limitations of research on the Inventory of positive law and research on legal system. The result of the research shows that the concept of harmonization of the regulation of the environment in the framework of sustainable development must be based on the principles, theories and philosophies which underlie the formation of a law. It should consider the characteristics of the Indonesian nation so that the rules can be easily implemented.
\end{abstract}

Key Words: Harmonization, Environment, Principles of Justice

\section{INTRODUCTION}

The Republic of Indonesia is known as a country rich in natural resources, both in the form of renewable and nonrenewable natural resources, as well as forming natural resources stock, such as watersheds, lakes, protected areas, coastal areas, swamps and peatlands, as well as natural resources commodities such as timber, rattan, minerals, oil and gas, fish and other mines are almost evenly distributed throughout the sovereign territory of the Republic of Indonesia. ${ }^{1}$

However, many environmental management are incompatible with and contradictory to the 1945 Constitution of the Unitary State of the Republic of Indonesia, which mandates that everyone is entitled to a healthy and healthy environment, and the management of natural resources and the national economy should be organized on a sustainable, fair, and environmentally friendly, but in practice many activities of natural resource management are destructive of the environment, and ignore the principles of sustainable, fair and environmentally sound. As a result of this contrary law practice we can see if in the past four decades if the management of natural resources especially in the mineral mining sector has been dominated by foreigners. ${ }^{2}$ Furthermore, the result of the gap and injustice in the management of natural resources cause damage and degradation of the environment both in quality and quantity as quoted from the following sources:

1. The rate of deforestation reaches one million hectares per year in the period 2000-2012 and a number of tropical forest species are threatened with extinction due to the controlled exploitation of forest resources;

2. Almost $95 \%$ of coral reefs in Indonesia are threatened by human activities, with more than $35 \%$ experiencing high or very high threats. Coral collection, bomb or poison (cyanide) fishing and seawater contamination by uncontrolled industrial waste disposal have caused coral reefs;

3. Approximately $65 \%$ of the 8.6 million hectares of mangrove forest (mangrove) 5.5 million hectares suffered serious damage in the period 1999-2005 due to illegal logging for firewood and converted into large aquaculture areas; Of the 3.1 million hectares of mangroves still in good condition in 2005, about 1.8 million hectares have been damaged;

4. Large open-scale mining activities have changed the landscape, which in addition to damaging the soil also removes the vegetation above it. The former mining lands form giant puddles, so that the expanse of the soil becomes arid and acidic due to tailings and waste rocks resulting from mining activities. ${ }^{3}$

1 Nyoman Nurjaya (et al)Laporan Akhir Tim Pengkajian Konstitusi Tentang Pengelolaan Sumber Daya Alam Untuk Menjamin Kemakmuran Rakyat, BPHN Kementerian Hukum dan HAM RI, Jakarta, 2014 h.8.9.

2 lbid, h. 10

3 National Geographic Indonesia, "Hutan Mangrove Indonesia Terus Berkurang", 30 Mei 2012, Nasional Geographic Indonesia, Jakarta. 
One of the factors that caused the occurrence because of the lack of harmonization of sectoral legislation in the field of environment. Theoretically, legislation is a system in which there can be no contradictory, interrelated legislation that is part of a national legal system. The overlapping of regulations governing the environment, due to the lack of integration of sectoral legislation, while the need for harmonious and integrated legislation in the management of the environment is necessary to achieve order, guarantee the certainty and protection of the law. ${ }^{4}$

Things that should be considered in the harmonization of the law in the field of the environment that is the nature of the environment where its nature is not static and proceeds continuously with the laws of nature, although there is a condition where the environment has the ability to withstand a variety of changes. So according to the experts if the environment is experiencing dynamics and evolving, either through a slow process (evolution) for example gradation from a good environment to an extreme environment, characterized by reduced biodiversity, drought, chemical conditions on the ground, fast (revolution) for example due to erupting volcanoes, earthquakes that change environmental conditions, soil structure and geology. ${ }^{5}$

If it refers to the above conditions, then the environment and ecosystems are not permanent or sustainable but are dynamic and changing as their development is influenced by two things: the human being as the dominant part of the environment and the factors within the environment itself. Therefore, the use of the term environmental preservation should be reviewed for its use in the laws and regulations relating to the environment. This is similar to what was delivered by Otto Soemarwoto who disagreed with the principle of environmental conservation which he said contradicted the nature of the development itself and argued that the more appropriate principle is the principle of continued carrying capacity. ${ }^{6}$

\section{RESEARCH METHODS}

This research uses normative juridical approach, through the approach of legislation approach, conceptual approach and anlytis approach. Limitations of research on the Inventory of positive law and research on legal system. This study used a qualitative approach applied by collecting qualitative data from previous research related to this research and supported by literature study. Through a qualitative approach, an interpretation of existing phenomena will be made to enrich the analysis and conclusion.

\section{DISCUSSION}

A good and healthy environment is the basic right of every Indonesian citizen as mandated in Article 28H of the 1945 Constitution of the State of the Republic of Indonesia (UUD NRI 1945). The environment associated with its elements implies the interaction between elements in it, including humans against other resources. ${ }^{7}$

The regulation of the National Law sectorally regulates the management of natural resources and the environment starting with the birth of Law Number 5 Year 19 Concerning Basic Regulation of Agrarian Principles, Law Number 5 Year 1967 on Basic Provisions of Forestry, Law Number 111967 on Basic Provisions of Mining, Law Number 11 Year 1974 on Irrigation, Law No. 4 of 1982 on Basic Principles of Environmental Management, and Law No. 9 of 1985 on Fisheries. ${ }^{8}$ However, the presence of this Law at the time was still very much oriented towards the spirit of exploitation of natural resources as a sector that supported the target of economic growth and increased state revenues, oriented and favored investors / investors for the benefit of profit in business, thus ignoring access and interests as well as turning off the economic potentials of people in the region, embracing the ideology of mastery and the utilization of natural resources centered so that the orientation of natural resource management is centralized, the management of natural resources using sectoral approach, so that natural resources are not seen as an integrated ecological system ecosystem), sectoral trends in authority and institutions have resulted in the absence of coordination and integration between sectors in natural resource management, and the lack of recognition and protection of indigenous and tribal peoples' rights $n$ facts of plural law in the control and utilization of natural resources and environment. ${ }^{9}$

4 Kusnu Goesniadhie, 2010, Harmonisasi Sistem Hukum; Mewujudkan Tata Pemerintahan yang Baik, Nasa Media, Malang, h. 1.

5 N.H.T. Siahaan, 2004, Hukum Lingkungan dan Ekologi Pembangunan, Penerbit Erlangga, Jakarta, h. 170.

6 Otto Soemarwoto dalam N.H.T. Siahaan, 2004, Hukum LIngkungan dan Ekologi Pembangunan, Penerbit Erlangga, Jakarta, h. 171

7 Maret Priyanta, Pembaharuan dan Harmonisasi Peraturan Perundang-Undangan Bidang Lingkungan dan Penataan Ruang Menuju Pembangunan Berkelanjutan, Hasanudin Law Review, Vol. 1, Issue 3, 2015, h.343.

8 Ibid. hal 322

9 Ibid. hal 323 
Furthermore, as a refinement of legislation, a number of efforts are made, among others, to enact legislation such as Law No. 5 of 1990 on Conservation of Biological Natural Resources and Ecosystems, Law Number 24 Year 1992 on Spatial Planning and Law Number 231997 on Environmental Management. However, fundamental issues in the management of natural resources and the environment remain unanswered within. substance and implementation of the law, because there are still substantial weaknesses that the government still dominates the role in the control and utilization of natural resources, the mechanism of integration and inter-sector coordination has not been regulated explicitly and in detail, the approach in the management of natural resources is not regulated comprehensively, the rights of indigenous peoples over the control and utilization of natural resources have not been acknowledged in an essential manner, the space for community participation and transparency in natural resource management is still limited, public accountability to the public in natural resource management has not been explicitly explicit. ${ }^{10}$

Although then following the enactment of Law Number 22 Year 2001 on Oil and Gas; Law Number 7 Year 2004 regarding Mineral and Coal Minerals; Law Number 18 Year 2004 regarding Plantation; Law Number 31 Year 2004 regarding Fisheries; Law Number 27 Year 2007 on the Management of Coastal Areas and Small Islands; and Law Number 4 Year 2009 regarding Mineral and Coal Mining; and Law Number 32 Year 2009 on Environmental Protection and Management; in lieu of previously enacted laws, but basic principles of natural resource and environmental management such as: the principles of conservation and sustainability of natural resource functions, the principles of transparency and community participation in natural resource management, the principle of decentralization of authority, the principle of free consent given initial information, recognition and protection of the rights of indigenous peoples, has not been accommodated and integrated in an intrinsic and proportional manner as a manifestation of the principles of justice, democracy and sustainability in the management of natural resources and the environment.

From the study of the ten laws relating to the environment and natural resource management mentioned above, then Indonesia from the perspective of state law in the form of legislation can be said to be a country likened to having a legal jungle. Very many state law products are established to regulate the management of natural resources and the environment, to the very private aspects of life are also regulated by the government. Consequently, in terms of regulation of environmental management and natural resources at the level of legislation, there are disharmonization of substance arrangement, inconsistency, overlapping, ambiguity, and contradiction between the law. the law on the one hand that governs natural resource management, particularly in the regulation of the authority of state institutions that are regulated sectorally, not in an integrated manner, in the management of natural resources.In addition, the disharmony of substantial arrangements relating to the principles of democracy in which the principles of transparency and public participation in decision-making or government policy are regulated not starting from the planning stage, but after the government's policy is made, especially in the aftermath of a region or after to investors issued by authorized officials. Then the principle of transparency and community participation is also not regulated in the stages of implementation, monitoring and evaluation in natural resource legislation. Similarly to the principle of sustainability, prudence is a key component in ensuring environmental sustainability, and this principle as an effort to prevent from the threat of environmental damage as a system of human life, from the above review on this principle several laws related to the management of resources nature and environment ignore the prudential aspect and for the principle of justice, aspects relating to the relationship of government and people in the context of nation and state is the recognition and protection of the existence of customary law community units and traditional rights over the control and utilization as well access to natural resources as their primary source of livelihood is also an aspect that has not yet gained maximum protection.

This section of researchers will examine what legal concepts are ideal for establishing harmonious, just, democratic and sustainable environmental laws. As stated in chapter two, that in response to the third formulation of the ideal legal concept to form a harmonious, just, democratic and sustainable law of the environment, legal theories to be used as analytical blades or frameworks of ideas are sovereign theory, state law, legal function theory, legal certainty theory, legal theory, and theory of justice.

In the theory of sovereignty as proposed by Jimly Ashhidiqie that there is actually one more theory of sovereignty other than that known so far, namely the sovereignty of the environment. Further his opinion that the idea of economic and environmental sovereignty can be developed in the context of power constructed in the mechanism of the relationship between God, Nature and Man. Because nature and man must live in equilibrium, and to ensure that balance is necessary for the presence of God, it also changes the way modern human's view of nature that was once anthropocentric to theocentrism. And these six teachings on sovereignty have been adopted into the 1945 Constitution of the State of the Republic of Indonesia, especially post amendments. ${ }^{11}$

$10 \quad$ Ibid hal. 324

11 Loc.cit Jimly Asshiddiqie h.96

DOI: $10.9790 / 0837-2308035458$

www.iosrjournals.org $56 \mid$ Page 
Whereas to establish environmental or legal laws on the management of natural resources that are just, democratic and sustainable, the concept of environmental sovereignty proposed by Jimly above can be used as the legal political basis in harmonizing the environmental law, moreover if the concept has been realized in the form of norms in the Constitution namely Article 33 paragraph (3) and Article $28 \mathrm{H}$ paragraph (1). Furthermore, Jimly puts it: "To ensure balance, the secular modern life needs to reconsider God's presence in the human way of thinking in dealing with the natural surroundings and even the whole realm, even God, Nature and Man must be seen to have the rights and context of his power each." 12

Whereas in addition to the concept of environmental sovereignty, to establish environmental or legal laws on the management of natural resources that are just, democratic and sustainable, shall the making of the Law on the field of environment and natural resource management pay attention to the approach of legal pluralism. The approach of legal pluralism, according to Werner Menski is much more profound, so that in order to understand law and order of law, the study of norms alone is almost never enough. We must also consider the values, facts, meanings, processes, structures, power relationships, personnel, and technology. ${ }^{13}$

This approach will lead us to the meaning of the concept of environmental justice, according to Subarkah law enforcement that uses legal pluralism approach is expected to realize environmental justice. This concept of environmental justice can be found in the values of Pancasila, especially the five principles of social justice for all Indonesians, the concept of social justice is in line with what John Rawls proposes that the main subject of justice is society, Rawls insists that the justice enforcement program the populist dimension should take into account the two principles of justice, namely: First, giving equal rights and opportunities to the widest basic freedom, equal freedom for everyone. Second, able to reorganize the socio-economic disparities that occur so as to provide reciprocal benefits for everyone, whether those from lucky or disadvantaged groups.

In the formulation of the Law on the field of environment and management of natural resources of justice can be viewed from two aspects, firstly; justice can be viewed as a virtue, arising from the individual's individual reflection of a good and ethical way of life (the idea of justice according to Plato), and second; justice that is seen as a virtue merely appears and exists in each individual's personal niche, but furthermore, justice is present in a situation and community of human life. Therefore Article $28 \mathrm{H}$ paragraph (1) stating that every person has the right to live physically and mentally prosperous, to live and get a good and healthy environment and entitled to receive health services. This indicates that the state is required to guarantee the fulfillment of the right of everyone to obtain a good and healthy living environment as part of the human rights of ecology.

Based on the description above, according to the opinion of the researcher, to form a harmonious, fair, democratic and sustainable environmental law, the concept of environmental sovereignty in the sense of creating a balance of rights between man and nature, with legal pluralism approach to realize environmental justice, references to establish norms in legislation governing the management of natural resources and the environment.

\section{CONCLUSION}

The concept of harmonization of legislation in the field of environment in the framework of sustainable development must be based on principles, theories and philosophies underlying the formation of a law. It should consider the characteristics of the Indonesian nation so that the rules can be easily implemented. Environmental laws and regulations are the basis for development planning. The direction of development on the basis of the realization of the state's goal for justice of present and future generations.

\section{DAFTAR PUSTAKA}

[1]. Nyoman Nurjaya (et al)Laporan Akhir Tim Pengkajian Konstitusi Tentang Pengelolaan Sumber Daya Alam Untuk Menjamin Kemakmuran Rakyat, BPHN Kementerian Hukum dan HAM RI, Jakarta, 2014

[2]. So Woong Kim, Kebijakan Hukum Pidana Dalam Upaya Penegakan Hukum Lingkungan Hidup, Jurnal Dinamika Hukum, Vol. 13, No. 3, 2013.

[3]. Djanggih, H., \& Ahmad, K. (2017). The Effectiveness of Indonesian National Police Function on Banggai Regency Police Investigation (Investigation Case Study Year 2008-2016). Jurnal Dinamika Hukum, Vol. 17, No. 2, 2017.

[4]. Djanggih, H. 2018. The Phenomenon Of Cyber Crimes Which Impact Children As Victims In Indonesia. Yuridika, Vol. 33, No. 2, 2018.

[5]. Maret Priyanta, Pembaharuan dan Harmonisasi Peraturan Perundang-Undangan Bidang Lingkungan dan Penataan Ruang Menuju Pembangunan Berkelanjutan, Hasanudin Law Review, Vol. 1, Issue 3, 2015.

[6]. Kantor Kementerian Negara Lingkungan Hidup, po cit; Chong K. Choi dan Saut Hutagalung, Op. cit; White More, Tropical Rain Forest for the fareast, Oxford University Press, 1994; Kantor Menteri Negara

12 Ibid, hal. 119

13 Werner Menski, hal.113-114, Perbandingan Hukum dalam konteks Global, sistem eropa, asia dan afrika. Nusa Media, Bandung. 2014. 
Kependudukan dan Lingkungan Hidup Indonesia 1990, Jakarta. Rheet Butler, "Environmental Impact of Mining in the Rainforest” Mongabay, 27 Juli 2012.

[7]. Kusnu Goesniadhie, 2010, Harmonisasi Sistem Hukum; Mewujudkan Tata Pemerintahan yang Baik, Nasa Media, Malang.

[8]. N.H.T. Siahaan, 2004, Hukum Lingkungan dan Ekologi Pembangunan, Penerbit Erlangga, Jakarta

[9]. Otto Soemarwoto dalam N.H.T. Siahaan, 2004, Hukum LIngkungan dan Ekologi Pembangunan, Penerbit Erlangga, Jakarta.

[10]. Werner Menski, hal.113-114, Perbandingan Hukum dalam konteks Global, sistem eropa, asia dan afrika Nusa Media, Bandung. 2014.

[11]. Subarkah, implementasi hukum progresif dalam pembangunan berkelanjutan ekologis, Jurnal Yudisial Vol 8 No.3 Desember 2015.

IOSR Journal of Humanities and Social Science (IOSR-JHSS) is UGC approved Journal with Sl. No. 5070, Journal no. 49323.

Said Sampara "Harmonization of Environmental Laws Based On Democracy Justice Principle and Sustainability." IOSR Journal Of Humanities And Social Science (IOSR-JHSS). vol. 23 no. 08,2018 , pp. 54-58. 